\title{
Cytotoxic, DNA binding, DNA cleavage and antibacterial studies of ruthenium-fluoroquinolone complexes
}

\author{
MOHAN N PATEL*, HARDIK N JOSHI and CHINTAN R PATEL \\ Department of Chemistry, Sardar Patel University, Vallabh Vidyanagar, 388 120, India \\ e-mail: jeenen@gmail.com
}

MS received 3 August 2013; revised 12 November 2013; accepted 16 November 2013

\begin{abstract}
Six new Ru(II) and Ru(III) complexes have been synthesized and characterized by elemental analysis, LC-MS, electronic spectra, IR spectra and magnetic moment measurements. DNA-binding properties of $\mathrm{Ru}$ complexes have been studied by means of absorption spectrophotometry and viscosity measurements as well as their HS DNA cleavage properties by means of agarose gel electrophoresis. The experimental results show that all the complexes can bind to DNA via partial intercalative mode. The $K_{\mathrm{b}}$ values of complexes were found in the range $2.14 \times 10^{4}$ to $2.70 \times 10^{5} \mathrm{M}^{-1}$. All the complexes show excellent efficiency of cleaving DNA than respective fluoroquinolones. Brine shrimp lethality bioassay has been performed to check the cytotoxic activity. The $\mathrm{IC}_{50}$ values of the complexes are in the range of 6.27 to $16.05 \mu \mathrm{g} \mathrm{mL}^{-1}$.
\end{abstract}

Keywords. Ruthenium; fluoroquinolone; $\mathrm{LC}_{50}$; partial intercalation; HS DNA.

\section{Introduction}

It is well-known that deoxyribonucleic acid (DNA) plays an important role in the life process since it contains all the genetic information for cellular function. However, DNA molecules are prone to be damaged under various conditions like interactions with some molecules. This damage may cause various pathological changes in living organisms, which is due to their possible application as new therapeutic agents and their photochemical properties which make them potential probes of DNA structure and conformation. ${ }^{1-3}$ The binding interaction of transition metal complexes with DNA is of interest for both therapeutic and scientific reasons. ${ }^{4}$ Many transition metal complexes are known to bind to DNA via both covalent and non-covalent interactions. In covalent binding the labile ligand of the complexes is replaced by a nitrogen base of DNA. On the other hand, the non-covalent DNA interactions include intercalative, electrostatic and groove (surface) binding of cationic metal complexes along outside of DNA helix, major or minor groove.

Metals are considered essential to a human body being an integral part of an organic structure in performing physiologically important and vital functions, in the body. ${ }^{5}$ It seems that the role of metal ions is imperative for the way of function of fluoroquinolones. The synthesis and characterization of new metal complexes

\footnotetext{
*For correspondence
}

with fluoroquinolones are of great importance for better understanding of the drug-metal ion interactions. ${ }^{6}$ It was suggested that the reactions of metal ions with fluoroquinolones were essential for the activity of these antimicrobial agents, and the metal ions (magnesium, copper, and iron) may bridge the binding of the quinolone to DNA gyrase or of bacterial DNA directly. ${ }^{7,8}$ In recent years, a lot of work has been done on the interaction of the quinolones pefloxacin, ofloxacin and sparfloxacin with diverse metal ions. ${ }^{9-17}$

In continuation of our previous work, ${ }^{18}$ this paper mainly focuses on exploring the trend in DNA-binding affinities of six complexes and the important differences in some related properties. Understanding the features that contribute to recognition of DNA by small ligands or metal complexes is crucial for the development of drugs targeted at DNA. We hope the results will be of value in further understanding DNA binding, and the efficiency of DNA recognition and cleavage by $\mathrm{Ru}(\mathrm{II})$ and $\mathrm{Ru}(\mathrm{III})$ complexes.

\section{Experimental}

\subsection{Reagent}

All chemicals and solvents used were of analytical grade. Pefloxacin, ofloxacin and sparfloxacin were generously supplied by Bayer AG (Wuppertal, Germany). Ruthenium trichloride was purchased from Chemport 
(Mumbai, India). Ethidium bromide, bromophenol blue, agarose, xylene cyanol FF and Luria Broth (LB) were purchased from Himedia (India). Acetic acid and EDTA were purchased from Sd fine Chemicals (India). The starting complex $\left[\mathrm{RuCl}_{3}\left(\mathrm{PPh}_{3}\right)_{3}\right]$ was prepared by reported method. ${ }^{19}$

\subsection{Physical measurement}

The elemental analysis $(\mathrm{C}, \mathrm{H}$ and $\mathrm{N})$ of the synthesized complexes has been performed with a model 240 Perkin Elmer elemental analyzer. Room temperature magnetic measurement of the complexes has been carried out using a Gouy magnetic balance. The Gouy tube has been calibrated using mercury(II)tetrathiocyanatocobaltate(II) as the calibrant $\left(\chi_{\mathrm{g}}=16.44 \times 10^{-6} \mathrm{cgs}\right.$ units at $\left.20^{\circ} \mathrm{C}\right)$. The electronic spectra have been recorded on a UV-160A UV-Visible spectrophotometer, Shimadzu, Kyoto (Japan). Infrared spectra have been recorded on a FT-IR ABB Bomen MB 3000 spectrophotometer as $\mathrm{KBr}$ pellets in the range $4000-400 \mathrm{~cm}^{-1}$. The LC-MS have been recorded using Thermo Scientific mass spectrophotometer (USA).The minimum inhibitory concentration (MIC) study has been performed by means of laminar air flow cabinet Toshiba, Delhi (India).

\subsection{Synthesis of complexes}

2.3a $\left[R u(P F L)\left(P P h_{3}\right)_{2} C l_{2}\right](\mathbf{1}):$ The $\left[\mathrm{RuCl}_{3}\left(\mathrm{PPh}_{3}\right)_{3}\right]$ $(0.1 \mathrm{mmol})$ in toluene and a methanolic solution of the pefloxacin $(0.1 \mathrm{mmol})$ in presence of $\mathrm{CH}_{3} \mathrm{ONa}$ has been mixed in 1:1 molar ratio and refluxed for 4-5 h. Colour of the solution was changed after the addition of drug which indicates the formation of complex. The resulting solution has been concentrated to small volume on a rotary evaporator and the product has been separated by the addition of small amount of pet-ether (60$80^{\circ} \mathrm{C}$ ). The compound that separated has been filtered, washed with toluene followed by ether, dried in vacuo over anhydrous $\mathrm{CaCl}_{2}$, then recrystallized from 1:2 (v:v) chloroform-pet ether $\left(60-80^{\circ} \mathrm{C}\right)$ mixture (scheme 1). Yield: $57.9 \%$, m.p.: $>300^{\circ} \mathrm{C}, \mu_{e f f}: 1.96$ B.M. Anal. Calcd. for: $\mathrm{C}_{53} \mathrm{H}_{49} \mathrm{Cl}_{2} \mathrm{FN}_{3} \mathrm{O}_{3} \mathrm{P}_{2} \mathrm{Ru}$ (1028.90): C, 61.87; H, 4.80; N, 4.08. Found: C, 61.70; H, 4.59; N, 3.90\%. UV-Vis $\lambda(\mathrm{nm})\left(\varepsilon, \mathrm{M}^{-1} \mathrm{~cm}^{-1}\right)$ : as solid: $620,340,284$, 278; as solution: 614(244), 336(8297), 281(19646), $274(19829), \mathrm{m} / \mathrm{z}=1028.27$.

2.3b $\quad\left[\mathrm{Ru}(\mathrm{OFL})\left(\mathrm{PPh}_{3}\right)_{2} \mathrm{Cl}_{2}\right](\mathbf{2}): \quad$ Complex $\mathbf{2}$ has been synthesized using ofloxacin by above method. Yield: 52.1\%, m.p.: $263^{\circ} \mathrm{C}, \mu_{e f f}$ : 1.91 B.M. Anal. Calcd. for:
$\mathrm{C}_{53} \mathrm{H}_{47} \mathrm{Cl}_{2} \mathrm{FN}_{3} \mathrm{O}_{3} \mathrm{P}_{2} \mathrm{Ru}$ (1026.88): C, 61.99; H, 4.61; $\mathrm{N}, 4.09$. Found: C, 61.85; H, 4.48; N, 3.87\%. UVVis $\lambda(\mathrm{nm})\left(\varepsilon, \mathrm{M}^{-1} \mathrm{~cm}^{-1}\right)$ : as solid: $620,304,279$, 272; as solution: 616(305), 299(18913), 273.5(11622), $266(10829), \mathrm{m} / \mathrm{z}=1026.39$.

2.3c $\quad\left[\mathrm{Ru}(\mathrm{SPF})\left(\mathrm{PPh}_{3}\right)_{2} \mathrm{Cl}_{2}\right](\mathbf{3}): \quad$ Complex 3 has been synthesized using sparfloxacin by above method. Yield: 51.7\%, m.p.: $271^{\circ} \mathrm{C}, \mu_{e f f}: 1.89$ B.M. Anal. Calcd. for: $\mathrm{C}_{55} \mathrm{H}_{51} \mathrm{Cl}_{2} \mathrm{~F}_{2} \mathrm{~N}_{4} \mathrm{O}_{3} \mathrm{P}_{2} \mathrm{Ru}(1087.94): \mathrm{C}, 60.92 ; \mathrm{H}, 4.72 ; \mathrm{N}$, 5.15. Found: C, 60.71; H, 4.56; N, 4.94. UV-Vis $\lambda(n m)$ $\left(\varepsilon, \mathrm{M}^{-1} \mathrm{~cm}^{-1}\right)$ : as solid: $628,348,297,274$; as solution: 623(335), 344.5(7626), 290(12019), 276(11683), $\mathrm{m} / \mathrm{z}=$ 1087.25.

2.3d $\quad\left[R u(P F L)\left(P P h_{3}\right)_{3} C l\right](4):$ The $\left[\mathrm{RuCl}_{3}\left(\mathrm{PPh}_{3}\right)_{3}\right]$ $(0.1 \mathrm{mmol}$ in $20 \mathrm{~mL}$ toluene) and a methanolic solution of the pefloxacin $(0.1 \mathrm{mmol})$ in presence of $\mathrm{CH}_{3} \mathrm{ONa}$, methanolic solution of triethylamine $(0.1 \mathrm{mmol})$ and methanolic solution of lithium chloride $(0.4 \mathrm{mmol})$ have been mixed and refluxed for $4-5 \mathrm{~h}$. The resulting solution has been concentrated to small volume on a rotary evaporator and the product was separated by the addition of small amount of pet-ether $\left(60-80^{\circ} \mathrm{C}\right)$. The compound that separated has been filtered, washed with toluene followed by ether, dried in vacuo over anhydrous $\mathrm{CaCl}_{2}$, then recrystallized from 1:2 (v:v) chloroform-pet ether $\left(60-80^{\circ} \mathrm{C}\right)$ mixture (scheme 1).

Yield: $53.8 \%$, m.p.: $285^{\circ} \mathrm{C}$, Anal. Calcd. for: $\mathrm{C}_{71} \mathrm{H}_{64} \mathrm{ClFN}_{3} \mathrm{O}_{3} \mathrm{P}_{3} \mathrm{Ru}$ (1255.73): C, 67.91; H, 5.14; N, 3.35. Found: $\mathrm{C}, 67.70 ; \mathrm{H}, 4.96 ; \mathrm{N}, 3.21 \%$. UV-Vis $\lambda$ $(\mathrm{nm})\left(\varepsilon, \mathrm{M}^{-1} \mathrm{~cm}^{-1}\right)$ : as solid: $595,310,270$; as solution: 591(884), 305(20530), 263(14734), $\mathrm{m} / \mathrm{z}=1255.23$.

2.3e $\quad\left[\mathrm{Ru}(\mathrm{OFL})\left(\mathrm{PPh}_{3}\right)_{3} \mathrm{Cl}\right](\mathbf{5}):$ Complex $\mathbf{5}$ has been synthesized using ofloxacin by above method. Yield: $57.6 \%$, m.p.: $>300^{\circ} \mathrm{C}$, Anal. Calcd. for: $\mathrm{C}_{72} \mathrm{H}_{64} \mathrm{ClFN}_{3}-$ $\mathrm{O}_{4} \mathrm{P}_{3} \mathrm{Ru}$ (1283.30): C, 67.36; H, 5.03; N, 3.27. Found: C, 67.21; H, 4.86; N, 3.11\%. UV-Vis $\lambda(\mathrm{nm})\left(\varepsilon, \mathrm{M}^{-1}\right.$ $\left.\mathrm{cm}^{-1}\right)$ : as solid: $609,344,290$; as solution: $605(213)$, 338(6284), 286(13209), $\mathrm{m} / \mathrm{z}=1283.42$.

2.3f $\quad\left[R u(S P F)\left(P P h_{3}\right)_{3} C l\right](6)$ : Complex 6 has been synthesized using sparfloxacin by above method. Yield: $55.6 \%$, m.p.: $266^{\circ} \mathrm{C}$, Anal. Calcd. for: $\mathrm{C}_{73} \mathrm{H}_{66} \mathrm{ClF}_{2} \mathrm{~N}_{4} \mathrm{O}_{3} \mathrm{P}_{3} \mathrm{Ru}$ (1314.77): C, 66.69; H, 5.06; N, 4.26. Found: $\mathrm{C}, 66.50 ; \mathrm{H}, 4.86 ; \mathrm{N}, 4.09 \%$. UV-Vis $\lambda$ (nm) $\left(\varepsilon, \mathrm{M}^{-1} \mathrm{~cm}^{-1}\right)$ : as solid: $600,313,272$; as solution: 596(1098), 310.5(21629), 266(12599), $\mathrm{m} / \mathrm{z}=1314.29$. 


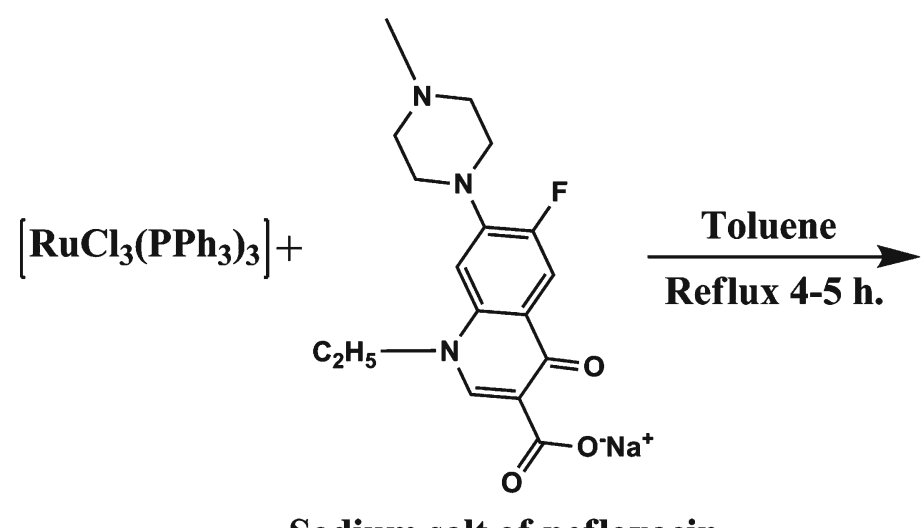

Sodium salt of pefloxacin

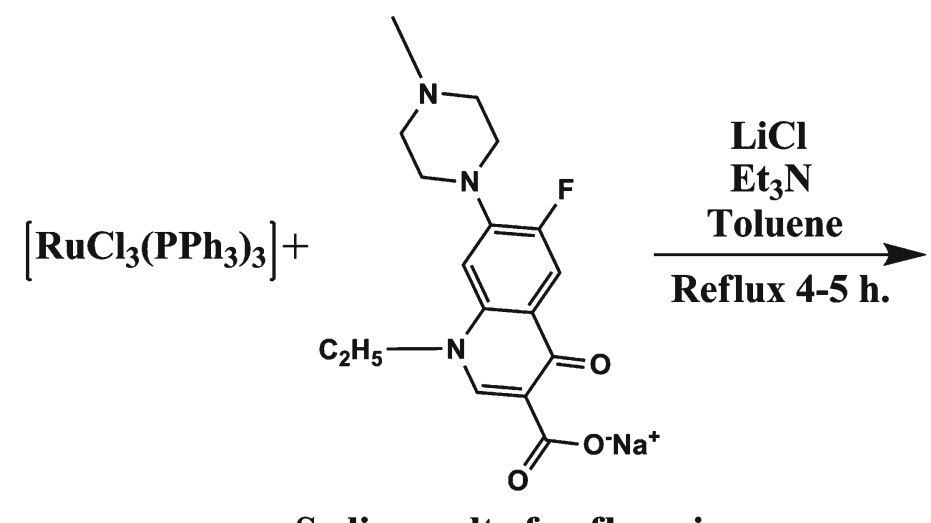

Sodium salt of pefloxacin

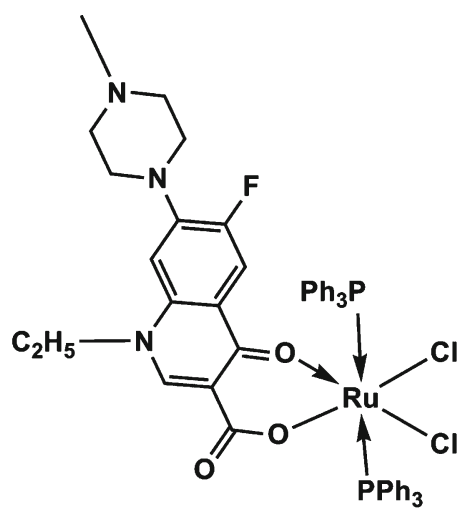

Complex 1

Scheme 1. Synthesis of $\left[\mathrm{Ru}(\mathrm{PFL})\left(\mathrm{PPh}_{3}\right)_{2} \mathrm{Cl}_{2}\right](\mathbf{1})$ and $\left[\mathrm{Ru}(\mathrm{PFL})\left(\mathrm{PPh}_{3}\right)_{3} \mathrm{Cl}\right](\mathbf{4})$.

\subsection{In vitro-antimicrobial screening}

To study the antibacterial activity of the compounds, we have used various microorganisms i.e., Escherichia coli (MTCC 433), Pseudomonas aeruginosa (MTCC P09), Serratia marcescens (MTCC 7103), Bacillus subtilis (MTCC 7193) and Staphylococcus aureus (MTCC 3160). Screening has been performed by determining the minimum inhibitory concentration (MIC) using LB as a medium. Cultures for $\mathrm{Gram}^{(+v e)}$ and $\mathrm{Gram}^{(-v e)}$ microorganisms were incubated at $37^{\circ} \mathrm{C}$. Since the compounds are water insoluble, samples have been dissolved in DMSO. A control test without active ingredient has also been performed. ${ }^{20}$ The MIC has been determined using two-fold serial dilutions in liquid media containing the test compound. A preculture of bacteria has been grown in LB overnight at the optimal temperature for each species. We monitored bacterial growth by measuring the turbidity of the culture after $18 \mathrm{~h}$. If a certain concentration of a compound inhibited the bacterial growth, half the concentration of compound was then tested. This procedure has been carried out until we get a concentration where the bacteria grew normally. The lowest concentration which inhibits bacterial growth has been determined as the MIC value. All equipments and culture media used were sterile.

The bactericidal action of all compounds has been evaluated against same microorganisms. The inoculum was prepared by diluting an overnight culture of microorganisms grown in LB, to obtain $10^{6}$ viable bacteria/mL. Bacteria have been exposed to various concentrations of compounds. Control tubes without compound have been included in each run. The final volume was $1 \mathrm{~mL}$. Cultures have been incubated at $37^{\circ} \mathrm{C}$ for $2 \mathrm{~h}$. The $100 \mu \mathrm{L}$ bacterial culture from each dilution has been taken and spread over previously prepared agar plate. Then the plates were incubated for $24 \mathrm{~h}$. The number of colonies present on the plates have been counted. The number of colonies was in the range of 30-300. 


\subsection{DNA interaction study}

2.5a UV-Vis spectra of the complexes in the presence of buffered HS DNA solution: The absorption titrations of $\mathrm{Ru}(\mathrm{II})$ and $\mathrm{Ru}(\mathrm{III})$ complexes in the buffer have been performed by using a fixed complex concentration to which increments of the nucleic acid stock solution was done. Concentration of complex solutions employed was $20 \mu \mathrm{M}$. While measuring the absorption spectra, equal amount of DNA has been added to both complex solution and reference solution to eliminate the absorbance of DNA itself. After addition of equivalent amount of DNA to reference cell, incubation for $10 \mathrm{~min}$ at room temperature has been provided, followed by absorbance measurement. DNA mediated hypochromism (decrease in absorbance) or hyperchromism (increase in absorbance) for synthesized compounds has been calculated. The intrinsic binding constant $K_{\mathrm{b}}$ has been determined by making it subject in the following equation: ${ }^{21}$

$$
\frac{[\mathrm{DNA}]}{\left(\varepsilon_{\mathrm{a}}-\varepsilon_{\mathrm{f}}\right)}=\frac{[\mathrm{DNA}]}{\left(\varepsilon_{\mathrm{b}}-\varepsilon_{\mathrm{f}}\right)}+\frac{1}{K_{\mathrm{b}}\left(\varepsilon_{\mathrm{b}}-\varepsilon_{\mathrm{f}}\right)}
$$

where $\varepsilon_{\mathrm{a}}, \varepsilon_{\mathrm{f}}$ and $\varepsilon_{\mathrm{b}}$ corresponds to $\mathrm{A}_{\mathrm{obsd}} /[\mathrm{Ru}]$, the extinction coefficient for the free ruthenium complex, and the extinction coefficient for the ruthenium complex when fully bound to DNA, respectively. In plots of [DNA] $/\left(\varepsilon_{\mathrm{a}}-\varepsilon_{\mathrm{f}}\right)$ versus [DNA], $K_{\mathrm{b}}$ is given by the ratio of slope to the intercept.

2.5b Viscosity measurements: Viscosity measurements have been carried out using an Ubbelohde viscometer, immersed in a thermostatic water-bath that maintained at a constant temperature at $27 \pm 0.1^{\circ} \mathrm{C}$. The compounds have been titrated into the HS DNA solution which presented in the viscometer. The flow time of each sample has been measured by a digital stopwatch for three times, and an average one was calculated. Data are presented as $\left(\eta / \eta_{0}\right)^{1 / 3}$ vs. binding ratio, ${ }^{19}$ where $\eta$ and $\eta_{0}$ are the viscosity of HS DNA in the presence or absence of complex, respectively. Viscosity values have been calculated from the observed flow time of HS DNA containing solutions corrected from the flow time of buffer alone $\left(t_{0}\right), \eta \infty\left(t-t_{0}\right){ }^{22}$

2.5c Gel electrophoresis technique: For the gel electrophoresis experiment, a total volume of $15 \mu \mathrm{L}$ containing $300 \mu \mathrm{g} / \mathrm{mL}$ of pUC19 DNA in TE buffer (10 mM Tris, $1 \mathrm{mM}$ EDTA, $\mathrm{pH}$ 8) has been treated with different complexes $(200 \mu \mathrm{M})$. The mixture has been incubated for $24 \mathrm{~h}$ at $37^{\circ} \mathrm{C}$. Then the samples have been analysed on the basis of their charge and size difference on a $1 \%$ agarose gel bed consisting of
$0.5 \mu \mathrm{g} / \mathrm{mL}$ of ethidium bromide at $50 \mathrm{~V}$, after quenching the reaction with $5 \mu \mathrm{L}$ loading buffer (40\% sucrose, $0.2 \%$ bromophenol blue). The whole bed has been immersed in $1 \mathrm{X}$ TAE buffer $(0.04 \mathrm{M}$ Tris-Acetate, pH 8, 0.001 M EDTA). The bands have been visualized using UV light, then photographed. An estimation of intensity of the DNA bands has been done using AlphaDigiDoc ${ }^{\mathrm{TM}}$ RT. Version V.4.0.0 PC-Image software gel documentation system.

\subsection{Brine shrimp assay}

Cytotoxicity of the compounds has been tested by using brine shrimp lethality bioassay. The method of Meyer et $a .^{23}$ was adopted for this purpose. Artificial seawater has been prepared with commercial salt mixture and double distilled water. Brine shrimp (Artemia cysts) eggs have been hatched in a shallow rectangular plastic dish $(22 \times 32 \mathrm{~cm})$, filled with artificial seawater. An unequal partition has been made in the plastic dish with the help of a perforated device. Approximately $50 \mathrm{mg}$ of eggs have been sprinkled into the hatching chamber and has been opened to ordinary light. After hatching, active nauplii free from egg shells have been collected from brighter portion of the hatching chamber and were used for the assay. A sample of the test compound has been prepared by dissolving $10 \mathrm{mg}$ of each compound in $10 \mathrm{~mL}$ of DMSO. Choudhary et $a l{ }^{24}$ suggested that the compound should be prepared by dissolving in DMSO in the suggested maximum volume range of $2 \%$ to prevent possible false effects originated from DMSO's toxicity to the experimental results. Solutions have been transferred to 18 vials from the stock solutions in such an amount to make final concentration 4, 8, 12, 16 and $20 \mu \mathrm{g} \mathrm{mL}^{-1}$ (three sets for each dilutions were used for each test sample and mean of three sets were taken). Three vials have been kept as control having same amount of DMSO only. When the nauplii were ready, $1 \mathrm{~mL}$ of seawater and 10 nauplii have been added to each vial (30 nauplii/dilution) and the volume has been adjusted with artificial seawater to $2.5 \mathrm{~mL}$ per vial. After $24 \mathrm{~h}$. the number of survivors has been counted. ${ }^{25}$ Data have been analysed by simple method to determine the $\mathrm{LC}_{50}$ values, in which $\log$ of concentration of samples have been plotted against percentage of mortality of nauplii.

\section{Results and discussion}

\subsection{Magnetic moments and electronic spectra}

Magnetic susceptibility of the synthesized complexes was measured using Gouy magnetic balance at $300 \mathrm{~K}$. 
The magnetic moment value for complexes 1-3 lie in the range of 1.89-1.96 $\mathrm{BM}$, which confirms the presence of single unpaired electron in a low-spin $4 d^{5}$ configuration for ruthenium(III) ion in octahedral environment. ${ }^{26}$ While the magnetic moment value for complexes 4-6 are found to be zero which confirms the absence of unpaired electron in a lowspin $d^{6}$ - configuration for $\mathrm{Ru}(\mathrm{II})$ ion in octahedral environment. ${ }^{27}$ So, from the magnetic moment values, it is proved that in case of complexes $\mathbf{1}-\mathbf{3}$, the ruthenium is in +3 oxidation state, while in case of complexes $\mathbf{4 - 6}$, the ruthenium is in +2 oxidation state.

The solution of complexes is prepared in DMSO for recording UV-Visible spectra. The electronic spectra of complexes 1-3 showed bands in the 268-623 nm regions. The band in the $614-623 \mathrm{~nm}$ region have been assigned to the $\mathrm{d}-\mathrm{d}$ transition, which is in conformity with assignments made for the similar ruthenium(III) complexes. ${ }^{28-30}$ Other bands in the 344-268 nm region have been assigned to the charge transfer transitions. In general, the electronic spectra of all the complexes are characteristic of an octahedral environment around ruthenium(III) ions.

Complexes 4-6 are diamagnetic indicating the presence of ruthenium in +2 oxidation state in all the complexes. The electronic spectra of complexes 4-6 dissolved in DMSO, consists of various bands between 263 and $605 \mathrm{~nm}$ regions. The bands in the region 591$611 \mathrm{~nm}$ are assigned as $\mathrm{d}-\mathrm{d}$ transition. The other bands in the region of 338-263 $\mathrm{nm}$ are probably due to charge transfer transitions. The nature of the electronic spectra are similar to those observed for other octahedral ruthenium(II) complexes. ${ }^{31}$

\subsection{IR spectra}

In table 1 the most characteristic absorptions of IR spectra of the complexes are listed. In the IR spectra of complexes 1-6 the absorption of the $v(C=O)_{\text {carb }}$ of the free quinolone ligands at $1708-1730 \mathrm{~cm}^{-1}$ has disappeared and has been replaced by two very strong characteristic bands in the range of $1558-1583 \mathrm{~cm}^{-1}$ and $1335-1381 \mathrm{~cm}^{-1}$ which can be assigned as asymmetric, $v\left(\mathrm{CO}_{2}\right)_{\text {asym }}$, and symmetric, $v\left(\mathrm{CO}_{2}\right)_{\text {sym }}$, stretching $v(\mathrm{O}-\mathrm{C}-\mathrm{O})$ vibrations, respectively. The difference $\Delta v=v\left(\mathrm{CO}_{2}\right)_{\text {asym }}-v\left(\mathrm{CO}_{2}\right)_{\text {sym }}$ is a useful characteristic for determining the coordination mode of the carboxylato group of the ligands. For complexes 1-6, the $\Delta$ values fall in the range of $201-247 \mathrm{~cm}^{-1}$ indicating a monodentate coordination mode of the carboxylato group. ${ }^{32,33}$ Finally, the pyridone stretch $v(\mathrm{C}=\mathrm{O})_{\mathrm{p}}$ is shifted from $1624-1642 \mathrm{~cm}^{-1}$ in the free ligands to $1620-1628 \mathrm{~cm}^{-1}$ upon bonding. The overall changes of the IR spectra of the complexes suggest that fluoroquinolones are coordinated to the metal via the pyridone oxygen and one carboxylate oxygen. ${ }^{34-37}$

\subsection{Mass spectra}

Figure 1 represents the mass spectrum of complex 1. The proposed mass fragmentation pattern of complex 1 has been given in Supplementary material. The mass spectrum of complex $\mathbf{1}$ shows molecular ion peak at $\mathrm{m} / \mathrm{z}=1028.27,1030.21$ and 1032.24 are due to the presence of two chlorine atoms and it also confirms that chlorine atoms are attached to metal atom through covalent bond. The two peaks observed at $\mathrm{m} / \mathrm{z}$ $=993.30$ and 995 are due to loss of chlorine atom in the complex 1 . The peaks observed at $\mathrm{m} / \mathrm{z}=696.19$, 698.16 and 700.11 are due to loss of the pefloxacin. These peaks also confirm the presence of two chlorine atoms. The peaks observed at $\mathrm{m} / \mathrm{z}=333.07$ and 262.19 are observed due to pefloxacin and triphenylphosphine moieties, respectively.

Figure of mass spectrum and proposed mass fragmentation pattern of complex $\mathbf{4}$ has been provided in Supplementary material. The mass spectrum of complex 4 shows molecular ion peak at 1255.23 and 1257.29 are due to the presence of one chlorine atom and it also confirms that chlorine atom is attached to metal atom through covalent bond. The peak observed at $\mathrm{m} / \mathrm{z}=1220.34$ is due to loss of the chlorine atom in complex 4. The peak observed at $\mathrm{m} / \mathrm{z}=923.06$ is observed due to loss of pefloxacin. The peaks observed at $\mathrm{m} / \mathrm{z}=333.28$ and 262.38 are observed due to pefloxacin and triphenylphosphine moieties, respectively.

Following important points confirmed that the formation of $\mathrm{Ru}$ complexes having different oxidation states.

(i) $\mathrm{Ru}(\mathrm{III})$ complexes are reddish brown in colour while, $\mathrm{Ru}(\mathrm{II})$ complexes are dark green.

(ii) $\mathrm{Ru}(\mathrm{III})$ complexes are air stable while, $\mathrm{Ru}(\mathrm{II})$ complexes are air unstable.

(iii) $\mathrm{Ru}(\mathrm{III})$ complexes are paramagnetic while, $\mathrm{Ru}(\mathrm{II})$ complexes are diamagnetic in nature.

(iv) $\mathrm{Ru}(\mathrm{III})$ complexes have lower mass/charge ratio while, $\mathrm{Ru}(\mathrm{II})$ complexes have higher mass/charge ratio.

\subsection{In vitro-antimicrobial screening}

All the fluoroquinolones and their ruthenium complexes were screened in vitro for their growth inhibitory activity against the pathogenic bacteria E. coli, 
Table 1. Change in IR bands for interaction of fluoroquinolones with $\mathrm{Ru}(\mathrm{II})$ and $\mathrm{Ru}(\mathrm{III})$ in addition to triphenylphosphines $\left(4000-400 \mathrm{~cm}^{-1}\right)$.

\begin{tabular}{lccccc}
\hline Compounds & $v(\mathrm{C}=\mathrm{O}) \mathrm{cm}^{-1}$ pyridone & $v(\mathrm{COO})_{\text {asym }} \mathrm{cm}^{-1}$ & $v(\mathrm{COO})_{\text {sym }} \mathrm{cm}^{-1}$ & $\Delta v \mathrm{~cm}^{-1}$ & ${\text { Bands due to } \mathrm{PPh}_{3}}$ \\
\hline Pefloxacin & 1632 & $1716^{a}$ & - & - & - \\
Ofloxacin & 1634 & 1728 & - & - & - \\
Sparfloxacin & 1643 & 1714 & - & - & - \\
{$\left[\mathrm{Ru}(\mathrm{PFL})\left(\mathrm{PPh}_{3}\right)_{2} \mathrm{Cl}_{2}\right]$} & 1628 & 1582 & 1381 & 201 & $1450,1080,694$ \\
{$\left[\mathrm{Ru}(\mathrm{OFL})\left(\mathrm{PPh}_{3}\right)_{2} \mathrm{Cl}_{2}\right]$} & 1620 & 1582 & 1335 & 247 & $1443,1049,694$ \\
{$\left[\mathrm{Ru}(\mathrm{SPF})\left(\mathrm{PPh}_{3}\right)_{2} \mathrm{Cl} l_{2}\right]$} & 1628 & 1558 & 1355 & 203 & $1435,1095,694$ \\
{$\left[\mathrm{Ru}(\mathrm{PFL})\left(\mathrm{PPh}_{3}\right)_{3} \mathrm{Cl}\right]$} & 1628 & 1580 & 1342 & 238 & $1435,1065,694$ \\
{$\left[\mathrm{Ru}(\mathrm{OFL})\left(\mathrm{PPh}_{3}\right)_{3} \mathrm{Cl}\right]$} & 1628 & 1578 & 1370 & 213 & $1435,1065,694$ \\
{$\left[\mathrm{Ru}(\mathrm{SPF})\left(\mathrm{PPh}_{3}\right)_{3} \mathrm{Cl}\right]$} & 1628 & & 1348 & 230 & $1435,1065,694$ \\
\hline
\end{tabular}

${ }^{a}$ as $v(\mathrm{COOH})$

P. aeruginosa, $S$. marcescens, $B$. subtilis and $S$. aureus. The results indicate that the complexes exhibit considerable activity compared to free fluoroquinolones against the same microbes under identical experimental conditions and the toxicity of ruthenium chelate increases on increasing the concentration. In vitro antibacterial activity data of the pefloxacin, ofloxacin, sparfloxacin and synthesized complexes (1-6) are given in table 2. All the Ru(III) complexes (1-3) are active against all the microorganisms than those of respective fluoroquinolones. In case of $\mathrm{Ru}(\mathrm{II})$ complexes, complex $\mathbf{6}$ is more active against all the microorganisms than that of sparfloxacin. Complex $\mathbf{4}$ and complex $\mathbf{5}$ are less active against $S$. aureus and $P$. aeruginosa than pefloxacin and ofloxacin, respectively. Both these complexes are active than pefloxacin and ofloxacin against E. coli, $S$. marcescens and B. subtilis. Another interesting finding is $\mathrm{Ru}$ (III) complexes show better activity than $\mathrm{Ru}(\mathrm{II})$ complexes and free fluoroquinolones.

The possible mode of increased toxicity of the ruthenium complexes compared to that of the free ligands may be explained in terms of Tweedy's chelation theory. ${ }^{38}$ Chelation considerably reduces the polarity of

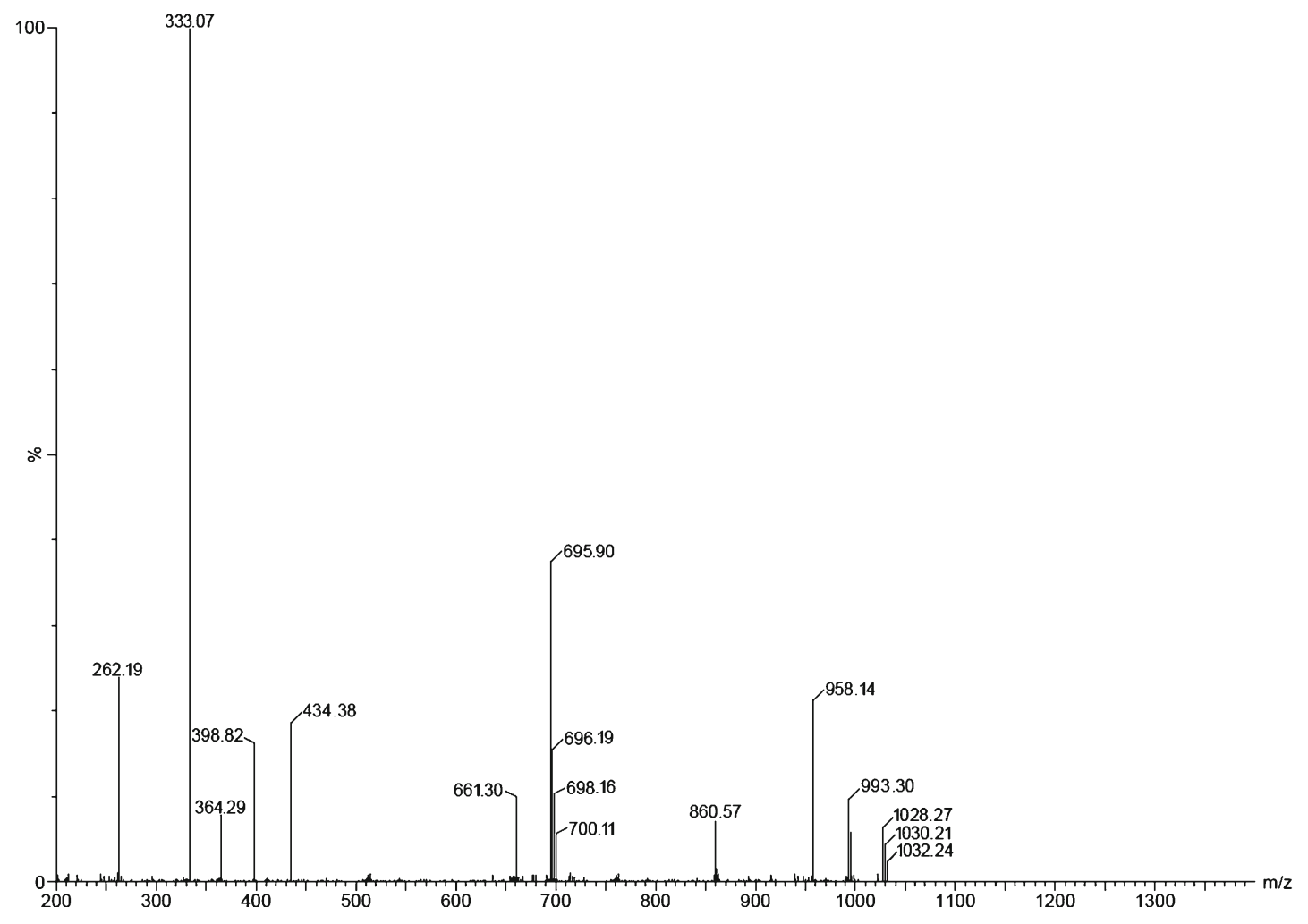

Figure 1. LC-mass spectrum of complex 1, i.e., $\left[\mathrm{Ru}(\mathrm{PFL})\left(\mathrm{PPh}_{3}\right)_{2} \mathrm{Cl}_{2}\right]$. 
Table 2. Bacteriostatic concentration of fluoroquinolones and complexes $(\mu \mathrm{M})$.

\begin{tabular}{|c|c|c|c|c|c|}
\hline \multirow[b]{2}{*}{ Compounds } & \multicolumn{2}{|c|}{ Gram-positive } & \multicolumn{2}{|c|}{ Gram-negative } & \multirow[b]{2}{*}{ E. coll } \\
\hline & S. aureus & B. subtilis & S. marcescens & P. aeruginosa & \\
\hline Pefloxacin & 1.9 & 2.2 & 4.8 & 5.4 & 2.44 \\
\hline Ofloxacin & 1.7 & 1.24 & 1.52 & 2.0 & 1.24 \\
\hline Sparfloxacin & 1.2 & 1.9 & 1.4 & 1.46 & 1.2 \\
\hline$\left[\mathrm{Ru}(\mathrm{PFL})\left(\mathrm{PPh}_{3}\right)_{2} \mathrm{Cl}_{2}\right]$ & 1.7 & 1.85 & 3.4 & 5.2 & 1.8 \\
\hline$\left[\mathrm{Ru}(\mathrm{OFL})\left(\mathrm{PPh}_{3}\right)_{2} \mathrm{Cl}_{2}\right]$ & 1.5 & 0.8 & 1.1 & 1.8 & 0.9 \\
\hline$\left[\mathrm{Ru}(\mathrm{SPF})\left(\mathrm{PPh}_{3}\right)_{2} \mathrm{Cl}_{2}\right]$ & 0.7 & 1.4 & 0.6 & 1.0 & 0.8 \\
\hline$\left[\mathrm{Ru}(\mathrm{PFL})\left(\mathrm{PPh}_{3}\right)_{3} \mathrm{Cl}\right]$ & 2.2 & 2.1 & 3.8 & 5.7 & 2.2 \\
\hline$\left[\mathrm{Ru}(\mathrm{OFL})\left(\mathrm{PPh}_{3}\right)_{3} \mathrm{Cl}\right]$ & 1.9 & 1.0 & 1.2 & 2.2 & 1.1 \\
\hline$\left[\mathrm{Ru}(\mathrm{SPF})\left(\mathrm{PPh}_{3}\right)_{3} \mathrm{Cl}\right]$ & 1.0 & 1.7 & 0.8 & 1.3 & 1.0 \\
\hline
\end{tabular}

the metal ion because of partial sharing of its positive charge with donor groups and possible $\pi$-electron delocalization over the whole chelate ring. Such a chelation could enhance the lipophililic character of the central metal atom, which subsequently favours it permeation through the lipid layers of cell membrane ${ }^{39}$ and blocking the metal binding sites on enzymes of microorganism. The variation in the effectiveness of different compound against different organisms depends either on the impermeability of the cells of the microbes or differences in ribosomes of microbial cells.

In addition to our study regarding MIC, we performed bactericidal activity in terms of $\mathrm{CFU} / \mathrm{mL}$ of metal complexes against same microorganisms (two $\operatorname{Gram}^{(+v e)}$ and three $\left.\operatorname{Gram}^{(-v e)}\right)$. Results reveal that decrease in number of colonies with increasing concentration of compounds. The results are shown in figure 2 for all the complexes against $S$. aureus. The number of colonies counted in this technique is in the range 30-300.

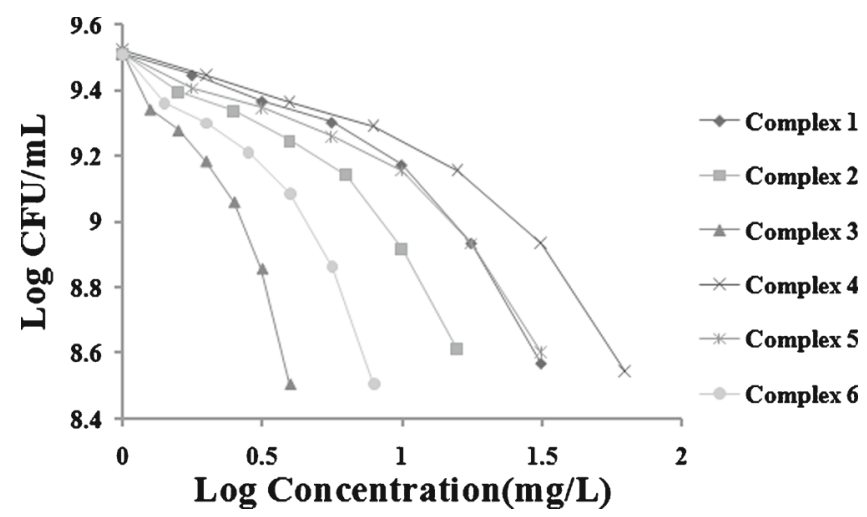

Figure 2. Relationship between concentration and bactericidal activity of all complexes against $S$. aureus.

\subsection{DNA interaction study}

3.5a UV-Vis spectra of the complexes in the presence of buffered HS DNA solution: In general, metal complexes can bind to DNA via both covalent and non-covalent interactions. ${ }^{40-42}$ These different modes of binding can be monitored by following the changes in the wavelength and intensity of absorption of a particular peak exhibited by the unbound complex. A decrease in absorbance (hypochromism) or an increase in absorbance (hyperchromicity) upon addition of DNA to a compound in solution is indicative of an interaction between these molecules. ${ }^{43}$ An absorption spectrum of complexes with Herring Sperm DNA was recorded for a constant concentration of complexes with varying concentration of DNA to obtain different DNA:complex

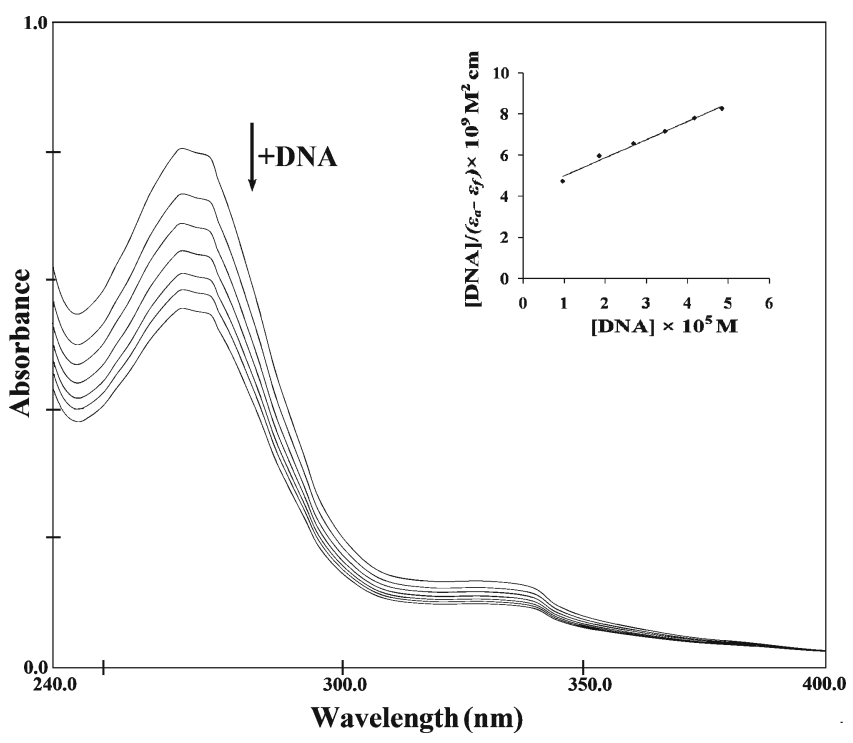

Figure 3. Electronic absorption spectra of $[\mathrm{Ru}(\mathrm{PFL})$ $\left.\left(\mathrm{PPh}_{3}\right)_{2} \mathrm{Cl}_{2}\right]$ in phosphate buffer $\left(\mathrm{Na}_{2} \mathrm{HPO}_{4} / \mathrm{NaH}_{2} \mathrm{PO}_{4}, \mathrm{pH}\right.$ 7.2) in the absence and presence of increasing amount of DNA. Inset: Plot of [DNA] $/\left(\varepsilon_{\mathrm{a}}-\varepsilon_{\mathrm{f}}\right)$ vs. [DNA]. Arrow shows the absorbance change upon increasing DNA concentrations. 


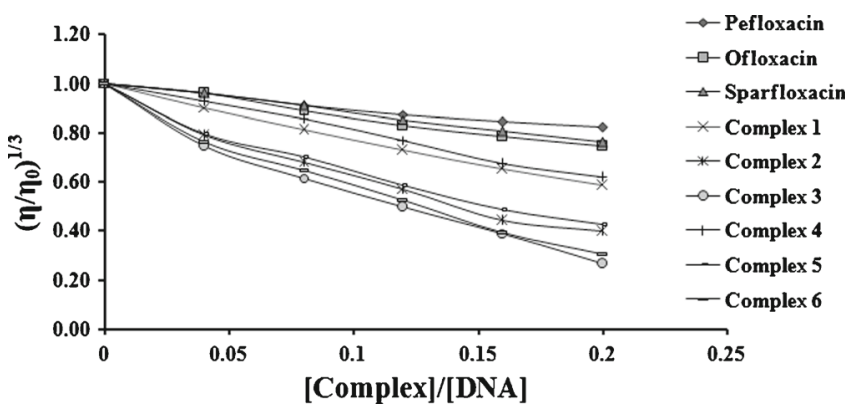

Figure 4. Effect on relative viscosity of DNA under the influence of increasing amount of complexes at $27 \pm 0.1^{\circ} \mathrm{C}$ in phosphate buffer $\left(\mathrm{Na}_{2} \mathrm{HPO}_{4} / \mathrm{NaH}_{2} \mathrm{PO}_{4}, \mathrm{pH}\right.$ 7.2).

mixing ratio. A representative titration curve is shown in figure 3. The extent of the binding strength of complexes was quantitatively determined by calculating intrinsic binding constant $K_{\mathrm{b}}$ ) of the complexes by monitoring the change in absorbance at various concentrations of DNA. From the plot of $[\mathrm{DNA}] /\left(\varepsilon_{\mathrm{a}}-\varepsilon_{\mathrm{f}}\right)$ versus [DNA] (inset, figure 4). The $K_{\mathrm{b}}$ values of complexes were found in the range $2.14 \times 10^{4}$ to $2.70 \times$ $10^{5} \mathrm{M}^{-1}$ and represented in table 3 . The $K_{\mathrm{b}}$ ) values of all the complexes are higher than free fluoroquinolones. The $K_{\mathrm{b}}$ ) values of all the complexes are lower than $\left[\mathrm{Ru}(\mathrm{PEF}) \mathrm{Cl}_{2}\left(\mathrm{H}_{2} \mathrm{O}\right)_{2}\right] .5 \mathrm{H}_{2} \mathrm{O}\left(5.00 \times 10^{7} \mathrm{M}^{-1}\right),{ }^{14}$ $\left[\mathrm{Ni}(\mathrm{sf})_{2}(\right.$ phen $\left.)\right]\left(1.13 \times 10^{6} \mathrm{M}^{-1}\right),{ }^{44} \mathrm{Ni}(\mathrm{sf})_{2}(\mathrm{py})_{2}$ $\left(3.87 \times 10^{7} \mathrm{M}^{-1}\right),{ }^{45}\left[\mathrm{Ni}(\mathrm{sf})_{2}\right.$ (bipy) $] 7.75 \times 10^{5},{ }^{46}$ $[\mathrm{Cu}(\mathrm{flmq})($ phen $) \mathrm{Cl}]\left(2.39 \times 10^{5}\right)$ and $\left[\mathrm{Cu}(\mathrm{flmq})_{2}(\text { py })_{2}\right]$ $\left(8.12 \times 10^{5}\right)^{47}$ and comparable to $\left.[\mathrm{Ru} \text { (cipro })_{3}\right] \cdot 4 \mathrm{H}_{2} \mathrm{O}$ $\left(2.50 \times 10^{4} \mathrm{M}^{-1}\right)^{12},\left[\mathrm{Ni}(\mathrm{sf})_{2}(\right.$ bipyam $\left.)\right] 2.23 \times 10^{4} .{ }^{46}$ Therefore, the above results indicate that the complexes may bind with DNA either via classical or via partial intercalative mode. The binding mode is further confirmed by viscosity measurements. For a particular drug, Ru(III) complexes have higher binding constant values than $\mathrm{Ru}$ (II) complexes. This observation suggest that $\mathrm{Ru}(\mathrm{III})$ complexes can bind with DNA better than $\mathrm{Ru}(\mathrm{II})$ complexes. 3.5b Viscosity measurements: As a means for further clarifying the binding of the ruthenium complexes, viscosity measurements were carried out on HS DNA by varying the concentration of the added complex. Spectroscopic data are necessary, but not sufficient to support a binding mode. Hydrodynamic measurements that are sensitive to length increase (for example, viscosity, sedimentation) are regarded as the most critical tests of binding in solution in the absence of crystallographic structure data. A classical intercalation model demands that the DNA helix lengthens as base pairs are separated to accommodate the binding ligand, which leads to an increase in the viscosity of DNA. ${ }^{48}$ However, a partial and/or non-classical intercalation of ligand may bend (or link) the DNA helix, resulting in decreasing its effective length and, concomitantly, its viscosity. ${ }^{49}$ The effect of increasing amount of complexes on the relative viscosity of HS DNA is shown in figure 3. For all complexes, relative viscosity of HS DNA solution is decreases upon increasing the concentration ratio of complex to HS DNA. This result is similar to the previously reported $\left[\mathrm{Ru}(\mathrm{dmp})_{2}(\mathrm{MCMIP})\right]\left(\mathrm{ClO}_{4}\right)_{2},{ }^{50}$ $\left[\mathrm{Ru}(\mathrm{dmb})_{2}(\mathrm{pdpt})\right]\left(\mathrm{ClO}_{4}\right)_{2} \cdot \mathrm{H}_{2} \mathrm{O} .{ }^{51}$ The partial intercalation from the minor/major groove may act as a 'wedge' to pry one side of a base-pair stack apart, as observed for the $\Delta-\left[\operatorname{Ru}(\mathrm{phen})_{3}\right]^{2+}, 52,53$ but does not fully separate the stack as required by the classical intercalation mode. This would cause a static bend or kink in the helix and decrease the viscosity of HS DNA. The viscosity of $\mathrm{Ru}$ (III) complexes is decreasing more than $\mathrm{Ru}(\mathrm{II})$ complexes which proves that $\mathrm{Ru}(\mathrm{III})$ complexes bind to $\mathrm{HS}$ DNA more strongly than Ru(II) complexes. Considering the results of spectroscopic and viscosity measurements synthetically, we suggest that complexes could bind to HS DNA by partial intercalation.

3.5c Gel electrophoresis technique: The potential of the present complexes to cleavage DNA was studied by gel electrophoresis using supercoiled pUC19 DNA.

Table 3. The binding constant $\left(K_{\mathrm{b}}\right)$ values of compounds.

\begin{tabular}{ll}
\hline Compounds & $K_{\mathrm{b}}\left(\mathrm{M}^{-1}\right)$ \\
\hline Pefloxacin & $2.31 \times 10^{3}$ \\
Ofloxacin & $2.56 \times 10^{3}$ \\
Sparfloxacin & $2.93 \times 10^{3}$ \\
{$\left[\mathrm{Ru}(\mathrm{PFL})\left(\mathrm{PPh}_{3}\right)_{2} \mathrm{Cl}_{2}\right]$} & $2.14 \times 10^{4}$ \\
{$\left[\mathrm{Ru}(\mathrm{OFL})\left(\mathrm{PPh}_{3}\right)_{2} \mathrm{Cl}_{2}\right]$} & $5.19 \times 10^{4}$ \\
{$\left[\mathrm{Ru}(\mathrm{SPF})\left(\mathrm{PPh}_{3}\right)_{2} \mathrm{Cl}_{2}\right]$} & $2.70 \times 10^{5}$ \\
{$\left[\mathrm{Ru}(\mathrm{PFL})\left(\mathrm{PPh}_{3}\right)_{3} \mathrm{Cl}\right]$} & $8.42 \times 10^{3}$ \\
{$\left[\mathrm{Ru}(\mathrm{OFL})\left(\mathrm{PPh}_{3}\right)_{3} \mathrm{Cl}\right]$} & $1.52 \times 10^{4}$ \\
{$\left[\mathrm{Ru}(\mathrm{SPF})\left(\mathrm{PPh}_{3}\right)_{3} \mathrm{Cl}\right]$} & $8.16 \times 10^{4}$ \\
\hline
\end{tabular}


Table 4. Complex mediated DNA cleavage data by gel electrophoresis.

\begin{tabular}{lccccc}
\hline Lane & Compound & Form I (SC) & Form II (OC) & Form III (LC) & \% Cleavage \\
\hline 1 & DNA & 86 & 14 & - & - \\
2 & RuCl & 83 & 17 & - & - \\
3 & Pefloxacin & 59 & 24 & 17 & 31.39 \\
4 & Ofloxacin & 75 & 15 & 10 & 12.79 \\
5 & Sparfloxacin & 52 & 29 & 19 & 39.53 \\
6 & {$\left[\mathrm{Ru}(\mathrm{PFL})\left(\mathrm{PPh}_{3}\right)_{2} \mathrm{Cl}_{2}\right](1)$} & 33 & 51 & 16 & 61.62 \\
7 & {$\left[\mathrm{Ru}(\mathrm{OFL})\left(\mathrm{PPh}_{3}\right)_{2} \mathrm{Cl}_{2}\right](2)$} & 35 & 49 & 16 & 59.30 \\
8 & {$\left[\mathrm{Ru}(\mathrm{SPF})\left(\mathrm{PPh}_{3}\right)_{2} \mathrm{Cl}_{2}\right](3)$} & 27 & 49 & 24 & 68.60 \\
9 & {$\left[\mathrm{Ru}(\mathrm{PFL})\left(\mathrm{PPh}_{3}\right)_{3} \mathrm{Cl}\right](4)$} & 37 & 46 & 17 & 56.97 \\
10 & {$\left[\mathrm{Ru}(\mathrm{OFL})\left(\mathrm{PPh}_{3}\right)_{3} \mathrm{Cl}\right](5)$} & 39 & 47 & 21 & 63.95 \\
11 & {$\left[\mathrm{Ru}(\mathrm{SPF})\left(\mathrm{PPh}_{3}\right)_{3} \mathrm{Cl}\right](6)$} & 31 & 48 & & 45 \\
\hline
\end{tabular}

DNA cleavage is controlled by relaxation of supercoiled form of pUC19 DNA into nicked circular and linear form. When circular plasmid DNA is submitted to electrophoresis, the fastest migration will be observed for the supercoiled form (Form I). If one strand is cleaved, the supercoiled form (SC) will relax to produce a slower-moving open circular form (OC, Form II). If both strands are cleaved, a linear form (L) (Form III) will be generated that migrates in between SC form and OC form. ${ }^{54}$ The data of the percentage cleavage of DNA are presented in table 4. As shown in figure 5, no obvious cleavage was observed for the control in which metal complex was absent (DNA alone). From the data, it is clear that complexes can cleave DNA more efficiently than the metal salt and respective free fluoroquinolones. The data show that cleavage efficiency of complex $\mathbf{3}$ is the highest, while complex $\mathbf{5}$ has the lowest cleavage efficiency. The $\mathrm{Ru}$ (III) complexes can cleave the DNA better than Ru(II) complexes. The different cleaving efficiency may be ascribed to the different DNA-binding affinity of $\mathrm{Ru}(\mathrm{II})$ and $\mathrm{Ru}(\mathrm{III})$ complexes.

\subsection{Brine shrimp assay}

The Brine shrimp lethality bioassay has been chosen to assess the in vitro cytotoxic effects of the compounds, as it is inexpensive, reliable and quick method for the purpose. ${ }^{23}$ The technique is easily mastered, of little cost, and utilizes small amount of test material. Since its introduction, this in vivo lethality test has been successfully employed for providing a frontline screen that can be backed up by more specific and more sophisticated bioassays once the active compounds have been isolated. Results for the lethality were noted in term of deaths of nauplii. The degree of lethality was found to be directly proportional to the concentration of the compounds. In other words, mortality increased gradually with the increase in concentration of the test samples. A plot of Log of sample's concentration versus percentage of mortality showed a linear correlation. From the graph, the $\mathrm{LC}_{50}$ values of the compounds were calculated and they were found in the range from 6.27 to $16.05 \mu \mathrm{g} \mathrm{mL}^{-1}$. From the data reported in table 5, complex $\mathbf{3}$ is the most potent amongst all the compounds.

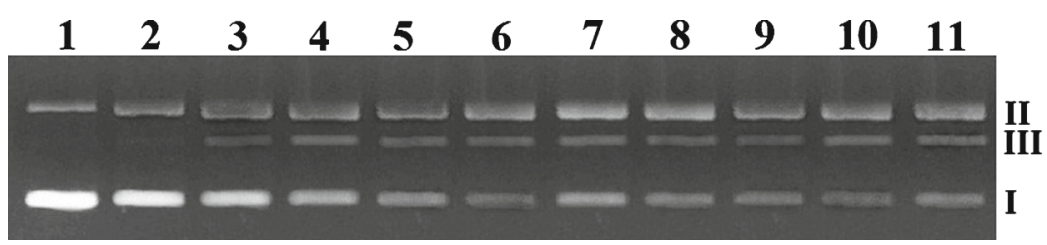

Figure 5. Gel electrophoresis diagram showing the cleavage of SC pUC19 DNA with series of copper(II) complex, incubated at $37^{\circ} \mathrm{C}$, using $1 \%$ agarose gel, at $50 \mathrm{mV}$ for $1.5 \mathrm{~h}$. Lane 1, DNA control; Lane 2, DNA $+\mathrm{RuCl}_{3}$; Lane 3, DNA + Pefloxacin; Lane 4, DNA + Ofloxacin; Lane 5, DNA + Sparfloxacin; Lane 6, DNA + [Ru(PFL)( $\left.\left(\mathrm{PPh}_{3}\right)_{2} \mathrm{Cl}_{2}\right] ;$ Lane 7, DNA $+\left[\mathrm{Ru}(\mathrm{OFL})\left(\mathrm{PPh}_{3}\right)_{2} \mathrm{Cl}_{2}\right] ;$ Lane 8, DNA + [Ru(SPF)( $\left.\left(\mathrm{PPh}_{3}\right)_{2} \mathrm{Cl}_{2}\right]$; Lane 9, DNA [Ru(PFL) $\left.\left(\mathrm{PPh}_{3}\right)_{3} \mathrm{Cl}\right]$; Lane 10, DNA + [Ru(OFL) $\left.\left(\mathrm{PPh}_{3}\right)_{3} \mathrm{Cl}\right]$; Lane $11 \mathrm{DNA}+\left[\mathrm{Ru}(\mathrm{SPF})\left(\mathrm{PPh}_{3}\right)_{3} \mathrm{Cl}\right]$. 
Table 5. Effect of compounds on brine shrimp lethality bioassay.

\begin{tabular}{lc}
\hline Compound & $\mathrm{LC}_{50}\left(\mu \mathrm{g} \mathrm{mL}{ }^{-1}\right)$ \\
\hline Pefloxacin & 218.77 \\
Ofloxacin & 245.47 \\
Sparfloxacin & 177.82 \\
{$\left[\mathrm{Ru}(\mathrm{PFL})\left(\mathrm{PPh}_{3}\right)_{2} \mathrm{Cl}_{2}\right]$} & 15.77 \\
{$\left[\mathrm{Ru}(\mathrm{OFL})\left(\mathrm{PPh}_{3}\right)_{2} \mathrm{Cl}_{2}\right]$} & 10.57 \\
{$\left[\mathrm{Ru}(\mathrm{SPF})\left(\mathrm{PPh}_{3}\right)_{2} \mathrm{Cl}_{2}\right]$} & 6.27 \\
{$\left[\mathrm{Ru}(\mathrm{PFL})\left(\mathrm{PPh}_{3}\right)_{3} \mathrm{Cl}\right]$} & 16.05 \\
{$\left[\mathrm{Ru}(\mathrm{OFL})\left(\mathrm{PPh}_{3}\right)_{3} \mathrm{Cl}\right]$} & 11.73 \\
{$\left[\mathrm{Ru}(\mathrm{SPF})\left(\mathrm{PPh}_{3}\right)_{3} \mathrm{Cl}\right]$} & 6.72 \\
\hline
\end{tabular}

Complex 4 is the least potent amongst the synthesized ones. The order of potency of compounds is $\mathbf{3}>\mathbf{6}>\mathbf{2}$ $>\mathbf{5}>\mathbf{1}>\mathbf{4}$. We have also performed the experiment in case of fluoroquinolones. The $\mathrm{LC}_{50}$ values for fluoroquinolones were in the range 177.82 to $245.57 \mu \mathrm{g}$ $\mathrm{mL}^{-1}$. From these results we can say that, all the complexes show good cytotoxic activity than the respective fluoroquinolones. Another interesting finding is for a particular drug, $\mathrm{Ru}$ (III) complexes have higher cytotoxic effect than $\mathrm{Ru}(\mathrm{II})$ complexes. The shrimp lethality assay is considered as a useful tool for preliminary assessment of toxicity. Further investigations are required to explore the exact mechanism of their cytotoxic properties, which may be helpful to explore new type of potent cytotoxic agents with the hope of adding new and alternative chemotherapeutic agents in clinical implications.

\section{Conclusion}

In summary, $\mathrm{Ru}(\mathrm{III})$ and $\mathrm{Ru}(\mathrm{II})$ complexes have been synthesized and characterized. Their DNA-binding behaviour has been examined by absorption spectroscopy and viscosity measurements. Results supported that $\mathrm{Ru}(\mathrm{III})$ and $\mathrm{Ru}(\mathrm{II})$ complexes can partially intercalate into DNA base pairs. The present results should be of value for the further understanding of the binding nature of ruthenium complexes to DNA, as well as laying the foundation for the rational design of novel probes for DNA. All the complexes bring about cleavage of plasmid DNA. DNA cleaving ability of complex $\mathbf{3}$ is higher compared to the rest of the complexes, metal salt and free fluoroquinolones. The compounds synthesized in the present study have shown good cytotoxic activity when screened using Brine Shrimp Lethality Assay. The most important conclusion from this article is that $\mathrm{Ru}(\mathrm{III})$ complexes are superior to $\mathrm{Ru}(\mathrm{II})$ complexes.

\section{Supplementary information}

Structures of fluoroquinolones and complexes, figures of colony forming units for microorganisms like $B$. subtilis, S. marcescens, $P$. aeruginosa and E. coli are given in supplementary materials (see www.ias.ac.in/ chemsci).

\section{Acknowledgements}

The authors thank the Head, Department of Chemistry, Sardar Patel University, India, for making it convenient to work in laboratory facility.

\section{References}

1. Navarro M, Fajardo E J C, Sierralta A, Mestre MF, Silva P, Arrieche D and Marchan E 2003 J. Biol. Inorg. Chem. 8401

2. Metcalfe C and Thomas J A 2003 Chem. Soc. Rev. 32 215

3. Arturo S, Giampaolo B, Giuseppe R, Maria L G and Salvatore T J 2004 J. Inorg. Biochem. 98589

4. Kelland L R 2005 Eur. J. Cancer 41971

5. Mertz W 1998 Biol. Trace. Elem. Res. 66185

6. Serafin A and Stanczak A 2009 Rus. J. Coordin. Chem. 3581

7. Shen L L and Perhet A G 1985 Proc. Natl. Acad. Sci. 82 307

8. Gellert M, Mizuuchi K, O'Dea M H and Nash H 1976 Proc. Natl. Acad. Sci. 733872

9. Efthimiadou E K, Karaliota A and Psomas G $2010 \mathrm{~J}$. Inorg. Biochem. 104455

10. Efthimiadou E K, Katsarou M E, Karaliota A and Psomas G 2008 J. Inorg. Biochem. 102910

11. Efthimiadou E K, Karaliota A and Psomas G 2008 Bioorg. Med. Chem. Lett. 184033

12. Tanimoto M K, Dias K, Dovidauskas S and Nikolaou S 2012 J. Coord. Chem. 651504

13. Turel I, Kljun J, Perdih F, Morozova E, Bakulev V, Kasyanenko N, Byl J A W and Osheroff N 2010 Inorg. Chem. 4910750

14. Muslu H, Golcu A, Tumer M and Ozsoz M $2011 \mathrm{~J}$. Coord. Chem. 643393 
15. Efthimiadou E K, Karaliota A and Psomas G 2008 Polyhedron 27349

16. Psomas G, Tarushi A and Efthimiadou E K 2008 Polyhedron 27133

17. Katsarou M E, Efthimiadou E K, Psomas G, Karaliota A and Vourloumis D $2008 \mathrm{~J}$. Med. Chem. 51470

18. Patel M N, Gandhi D S and Parmar P A 2010 Inorg. Chem. Commun. 13618

19. Chatt J, Leigh G J, Mingos D M P and Parke R J 1968 J. Chem. Soc. A 2636

20. Alexiou M, Tsivikas I, Dendreinou-Samara C, Pantazaki A A, Trikalitis P, Lalioti N, Kyriakidis D A and Kessissoglou D P 2003 J. Inorg. Biochem. 93 256

21. Tan L F and Chao H 2007 Inorg. Chim. Acta 360 2016

22. Basili S, Bergen A, Dall'Acqua F, Faccio A, Granzhan A, Ihmels H, Moro S and Viola G 2007 Biochemistry 46 12721

23. Meyer B N, Ferrigni N R, Putnam J E, Jacobsen L B, Nichols D E and McLaughlin J L 1982 Planta Med. 4531

24. Choudhary I M and Thomsen W J 2001 Bioassay techniques for drug development, Harwood Academic Publishers, $8-10$

25. Islam $M \quad R$, Islam $S M R$, Noman A S M, Khanam J A, Ali S M M, Alam S and Lee M W 2007 Mycobiology 35 25

26. Figgis B N 1966 Introduction to ligand field theory, Ist ed., Interscience Publishers, New York, p. 287

27. Griffith W P 1967 The chemistry of the rarer platinum metals, Interscience, London

28. Ballhausen C J 1962 Introduction to ligand field theory, McGarw Hill, New York

29. Lever A B P 1984 Inorganic Electronic Spectroscopy, 2nd ed., Elsevier, New York, p. 236

30. Balasubramanian K P, Parameswari K, Chinnusamy V, Prabhakaran R and Natarajan K 2006 Spectrochim. Acta Part A $\mathbf{6 5} 678$

31. Balasubramanian K P, Karvembu R, Prabhakaran R, Chinnusamy V and Natarajan K 2007 Spectrochim. Acta Part A 6850

32. Nakamoto K 1986 Infrared and Raman spectra of inorganic and coordination compounds, fourth ed., Wiley New York
33. Deacon G B and Phillips R J 1980 Coord. Chem. Rev. 33227

34. Turel I 2002 Coord. Chem. Rev. 23227

35. Efthimiadou E K, Thomadaki H, Sanakis Y, Raptopoulou C P, Katsaros N, Scorilas A, Karaliota A and Psomas G 2007 J. Inorg. Biochem. 10164

36. Efthimiadou E K, Sanakis Y, Katsaros N, Karaliota A and Psomas G 2007 Polyhedron 261148

37. Efthimiadou E K, Psomas G, Sanakis Y, Katsaros N and Karaliota A 2007 J. Inorg. Biochem. 101525

38. Tweedy B G 1964 Phytopathalogy 55910

39. Singh S C J, Gupta N and Singh R V 1995 Indian J. Chem. 34 A 733

40. Thorp H H 1993 J. Inorg. Organomet. Polymers 341.

41. Pyle A M and Barton J K 1990 Prog. Inorg. Chem. 38 413

42. Lippard S J 1978 Acc. Chem. Res. 11211

43. Richardson D R, Sharpe P C, Lovejoy D B, Senaratne D, Kalinowski D S, Islam M and Bernhardt P V 2006 J. Med. Chem. 496510

44. Skyrianou K C, Efthimiadou E K, Psycharis V, Terzis A, Kessissoglou D P and Psomas G 2009 J. Inorg. Biochem. 1031617

45. Skyrianou K C, Raptopoulou C P, Psycharis V, Kessissoglou D P and Psomas G 2009 Polyhedron 28 3265

46. Skyrianou K C, Perdih F, Papadopoulos A N, Turel I, Kessissoglou D P and Psomas G 2011 J. Inorg. Biochem. 1051273

47. Chalkidou E, Perdih F, Turel I, Kessissoglou D P and Psomas G 2012 J. Inorg. Biochem. 11355

48. Yang X, Liu Y, Yao S, Xia Y, Li Q, Zheng W, Chen L and Liu J 2011 J. Coord. Chem. 641491

49. Wang N, Lin Q Y, Feng J, Zhao Y L, Wang Y J and Li S K 2010 Inorg. Chim. Acta 3633399

50. Liu Y J, He J F, Yao J H, Mei W J, Wu F H and He L X 2009 J. Coord. Chem. 62665

51. Hong X L, Liang Z H and Zeng M H 2011 J. Coord. Chem. 643792

52. Satyanarayana S, Dabroniak J C and Chaires J B 1992 Biochemistry 319319

53. Satyanaryana S, Dabroniak J C and Chaires J B 1993 Biochemistry 322573

54. Barton J K and Raphael A L 1984 J. Am. Chem. Soc. 1062466 